\title{
Striking a Balance Between EU Competition Law and Public Procurement Law: Analysing the CJEU attempt in the Vossloh Laeis \\ case
}

\author{
Vittoria Moccia
}

\begin{abstract}
The present Insight offers an analysis of the judgment of the Court of Justice in the Vossloh Laeis case (judgement of 24 October 2018, case c-124/17, Vossloh Laeis GmbH v Stadwerke München $G m b H)$, which seeks answers to the extent of cooperation required from an economic operator wishing to demonstrate its reliability towards both the investigating and the contracting authorities. Taking into consideration the AG's opinion and the CJEU findings, this Insight exposes some of the legal obstacles that follow from the interplay between EU competition and public procurement law and the CJEU attempt at harmonizing two otherwise often conflicting policy areas.
\end{abstract}

\section{Keywords}

Vossloh Laeis; Directive 2014/24; self-cleaning programs; leniency agreements; public procurement; competition law.

\section{Introduction and Factual Background}

The EU is guided by its competences: areas where the EU is able to legislate, with or without the member states. Amongst these are, inter alia, public procurement and competition law. The former relates to substantive EU Directives that govern the process by which authorities purchase work, goods, or services from companies. ${ }^{1}$ While, the latter governs rules on cartels, market dominance, mergers, state aid, and the reporting of anti-competitive behaviour. ${ }^{2}$ In the pursuit of an ever-more integrated internal market and harmonized acquis communautaire these two EU competence areas often come into conflict. This mainly happens in two ways: (1) in tackling anticompetitive behaviours in the form of public tenders and (2) in curtailing distortion of competition as a consequence of public action and/or regulation. ${ }^{3}$ The extensive line of case law of the CJEU

\footnotetext{
${ }^{1}$ European Commission, Public Procurement - Internal Market, Industry, Entrepreneurship and Smes European Commission, in European Commission, 2020, https://ec.europa.eu/growth/single-market/publicprocurement_en\#: :text=Under\%20EU\%20public\%20procurement\%20rules,purchasing\%20works\%2C\%20g oods\%20or\%20services.\&text=To\%20support $\% 20$ the $\% 20$ further $\% 20$ uptake,innovative $\% 2 \mathrm{C} \% 20$ green $\% 20$ an $\mathrm{d} \% 20$ social\%20criteria.

2 European Commission, Competition Rules, in European Commission, 2020, https://ec.europa.eu/info/business-economy-euro/doing-business-eu/competition-rules_en.

${ }^{3}$ R. Paukste, Competition Law and Public Procurement - An Easy Catch for Competition Enforcers?, in Lexxion, 17 October 2019, https://www.lexxion.eu/en/coreblogpost/competition-law-and-public-procurementan-easy-catch-for-competition-enforcers/.
} 
has continuously exposed this clash and has attempted to give its interpretation in order to harmonize the EU rules.

One of the most relevant cases in this ambit is the judgment C-124/17 Vossloh Laeis GmbH V Stadwerke München GmbH (Vossloh Laeis) delivered on 25 October 2018. ${ }^{4}$ In this case, the German company Vossloh Laeis was accused and found guilty of taking part in agreements as part of a cartel. 5 This led to the establishment of a civil action against the German company from the contracting authority, Stadwerke München, for the harm caused upon them as a result of the participation in the cartel. ${ }^{6}$ Notwithstanding this pending action, Vossloh Laeis wished to participate in a new tendering procedure by Stadwerke München, bringing forth the self-cleaning defence in regards to certain measures it had adopted to prevent it from distorting competition once again. ${ }^{7}$ Doubtful of this, Stadwerke München asked Vossloh Laeis to provide the leniency decision of the Federal Cartel Office - the relevant competition authority - imposing the fine upon the German company, so as to examine the decision and the gravity of the infringement incurred. ${ }^{8}$ However, the German company refused to provide such document, arguing that it had already fully cooperated with the relevant competition authority, and that providing the leniency decision went beyond the scope of the requirements of the Procurement Directive 2014/24. ${ }^{9}$ Following this, Stadwerke München decided to prohibit the participation of the German company in the new tendering procedure and actions were brought against this exclusion by Vossloh Laeis before the national public procurement board. ${ }^{10}$ The national board decided to bring the case to the CJEU in the form of a preliminary ruling procedure to ask the extent of cooperation that is required from a tendered wishing to demonstrate its reliability towards both the investigating authority and the contracting authority. ${ }^{11}$

\section{The Opinion of the Advocate General}

The judgment in itself brought forward several questions including, inter alia, what should be interpreted as 'investigating authorities' under Article 57(6) of the Procurement Directive 2014/24. ${ }^{12}$ The AG opinion focuses on this issue, especially in regard to whether the investigating

\footnotetext{
${ }^{4}$ Court of Justice, judgement of 24 October 2018, case C-124/17, Vossloh Laeis GmbH v Stadwerke München $\mathrm{GmbH}$.

5 Vossloh Laeis GmbH v Stadwerke München GmbH, cit; P.A. Giosa, Enhancing Leniency Programme In Public Markets, in Journal of Antitrust Enforcement, 2020, p. 14.

${ }^{6}$ P.A. Giosa, Enhancing Leniency Programme In Public Markets, cit., p.14.

${ }^{7}$ Ibid.

${ }^{8}$ Ibid.
}

${ }^{9}$ Directive 2014/24 of the European Parliament and of the Council of 26 February 2014 on public procurement and repealing Directive 2004/18/EC Text with EEA relevance; P.A. Giosa, Enhancing Leniency Programme In Public Markets, cit., p.14.

${ }^{10}$ P.A. Giosa, Enhancing Leniency Programme In Public Markets, cit., p.14.

${ }^{11}$ P.A. Giosa, Enhancing Leniency Programme In Public Markets, cit., p. 14.

${ }^{12}$ Art. 57(6) of Directive 2014/24/EU, cit. 
authorities' must be interpreted as to include the contracting authorities and other entities. ${ }^{13}$ Firstly, in the paragraphs 40 and 41, the AG Campos focuses on the requirements listed under Article 57(6) and concludes that they are mandatory and, therefore, the contracting authorities and other entities cannot accept self-cleaning defences which do not satisfy them. ${ }^{14}$ Secondly, regarding the interpretation of the term 'investigating authorities', the AG claims that Article 57 only imposes some investigative powers upon contracting authorities and other entities, however does not consider them 'investigating authorities' per se. ${ }^{15}$ In this respect, however, AG Campos advocates that it does not go beyond the requirements of Article 57(6) of the Directive to demand that the tenderer, seeking to absolve itself through self-cleaning procedures, cooperates with investigating authorities and contracting authorities and other entities. ${ }^{16}$ Although the opinion brings attention to many relevant arguments for the interpretation of Article 57(6) of the Directive, it is still filled with a plethora of legal implications, beginning from the fact that it makes an effort to protect leniency programs without explicitly mentioning them. ${ }^{17}$ The rest of the case note will be dedicated to analysing the findings of the CJEU in the Vossloh Laeis judgment.

\section{Findings of the CJEU}

Amongst the most important findings of the CJEU is that the contracting authority can ask a tenderer to actively cooperate as to prove its reliability to the extent that the cooperation is strictly necessary for that examination. ${ }^{18}$ In this regard, the Court specified that the procurement entity can demand the company to provide the leniency decision even if the procurement of such may lead to the establishment of a civil claim. ${ }^{19}$ The disposition of such decision is sufficient to allow the contracting authority to prove the tenderer's reliability. ${ }^{20}$ The Court further clarified that the

13 Opinion of AG Campos delivered on 16 May 2018, case C-124/17, Vossloh Laeis GmbH v Stadwerke München GmbH; A. Sanchez-Graells, Bid Rigging, Self-Cleaning, Leniency And Claims For Damages: A Beautiful Procurement Mess? (C-124/17), in How to Crack a Nut, 22 May 2018, https://www.howtocrackanut.com/blog/2018/5/22/bid-rigging-self-cleaning-and-leniency-a-beautifulprocurement-mess-c- 12417.

14 Opinion of AG Campos, Vossloh Laeis GmbH v Stadwerke München GmbH, cit.; A. Sanchez-Graells, Bid Rigging, Self-Cleaning, Leniency And Claims For Damages: A Beautiful Procurement Mess? (C-124/17), cit.

15 A. Sanchez-Graells, Bid Rigging, Self-Cleaning, Leniency And Claims For Damages: A Beautiful Procurement Mess? (C-124/17), cit.

16 Opinion of AG Campos, Vossloh Laeis GmbH v Stadwerke München GmbH, cit., paras 55-61; A. SanchezGraells, Bid Rigging, Self-Cleaning, Leniency And Claims For Damages: A Beautiful Procurement Mess? (C124/17), cit.

17 A. Sanchez-Graells, Bid Rigging, Self-Cleaning, Leniency And Claims For Damages: A Beautiful Procurement Mess? (C-124/17), cit.

18 J. Bracker, ECJ On Reinstatement of Former Cartelists as Trusted Procurement Tenderers, in Ashurst.com, 26 November 2018, https://www.ashurst.com/en/news-and-insights/legal-updates/ecj-onreinstatement-of-former-cartelists-as-trusted-procurement-tenderers/.

19 J. Bracker, ECJ On Reinstatement of Former Cartelists as Trusted Procurement Tenderers, cit.

${ }^{20}$ P.A. Giosa, Enhancing Leniency Programme In Public Markets, cit., p. 15. 
contracting authorities have the right to ask for further information and clarification where the need to evaluate the self-cleaning measures is concerned. ${ }^{21}$ In order to establish the extent of collaboration, the Court has emphasized the role of the principle of proportionality in order to establish what is necessary to satisfy the goal at stance. ${ }^{22}$ In addition to this, the CJEU also gave its own interpretation to the term 'investigating authorities' under Article 57(6) of Directive 2014/24/EU. The Court concluded that the 'investigating authorities' are to include both the competition and the contracting authority. ${ }^{23}$ Thus, the undertaking is required to actively cooperate with both authorities.

\section{Legal Assessment}

Although the Court embarks on an extensive discussion on the extent of cooperation required on a tenderer wishing to re-establish its reliability, it still leaves plenty of doubt on the specific standard of care to employ in self-cleaning procedures and civil claims. ${ }^{24}$ For example, the Court fails to address which version of the leniency decision of the competition authority - whether the non-confidential or confidential one - is required from the contracting authority. ${ }^{25}$ In addition, the Court also fails to mentions guidelines as to which technical, organizational and personal measures must be carried out to ascertain an efficient self-cleaning process. ${ }^{26}$ Nonetheless this focus on the importance of re-establishing trustworthiness is an expression of a wide European consensus towards self-cleaning programs as mitigating factors for competition law breaches. ${ }^{27}$ This in itself brings plenty of legal implications as to how these programs should work in light of competition law, and more generally, which area of law - be it public procurement or competition law - should be offered more protection.

In this regard, it is important to highlight the links and clashes between EU competition law and public procurement law. Unlike for the policy area of competition law, the TFEU contains no explicit duties nor requirements for the policy area of public procurement law. ${ }^{28}$ The rules governing public procurement are only inferred from the TFEU four freedoms, in particular the free movement of goods, the freedom to provide services and the freedom of establishment. ${ }^{29}$ Despite this difference, the need for competitive practices in public procurement is an ever more present requirement in order to preserve these very Treaty principles, in particular the free

\footnotetext{
${ }^{21}$ Ibid.

22 Ibid., p. 16.

${ }^{23}$ Ibid.

${ }^{24}$ J. Bracker, ECJ On Reinstatement of Former Cartelists as Trusted Procurement Tenderers, cit.

${ }^{25}$ Ibid.

${ }^{26}$ Ibid.

${ }^{27}$ Ibid.

${ }^{28}$ Consolidated Version of the Treaty on the Functioning of the European Union (TFEU) [2016] OJ C202/1, Title VII; M. Werner, Recent CJEU Case Law: Core Notions And Principles \& Exceptions, Germany, 2019.

${ }^{29}$ Arts 34, 56 and 59 of TFEU, cit.
} 
movement of goods and services, the right to establishment as well as the prohibition of discrimination..$^{30}$

One of the ways in which the two policy areas clash is in the enforcement of Article 57 of Directive 2014/24. This provision offers both mandatory and discretionary grounds of exclusion under which contracting authorities ought or may disqualify economic operators. ${ }^{31}$ The protection of this provision has led to a system called 'self-cleaning' programs whereby economic undertakings that wish to absolve themselves through an exclusion ground can prove their reliability and may thus be allowed to participate in future procurement processes. ${ }^{32}$ However, the discretion left to contracting authorities per se conflicts with well-established EU principles of equal treatment, transparency and proportionality. As stressed by the CJEU in the field of public procurement law, a transparent procedure is one which is outlined by clear and accessible procedural rules. ${ }^{33}$ Specifically in regards to contracting authorities, the Court has stated in the Costa and Cifone case that the discretionary rules applied by contracting authorities ought to be "drawn up in a clear, precise and unequivocal manner, to make it possible for all reasonably informed tenders exercising ordinary care to understand their exact significance and interpret them in the same way, and to circumscribe the contracting authority's discretion." 34

In addition, the lack of clear discretionary rules for contracting authorities also leads to potential breaches of equal treatment as it is challenging to prove that they are treating similar undertakings who trigger similar exclusion grounds in an equal fashion if there are no transparent, strict nor accessible procedural rules to testify such treatment. ${ }^{35}$ Consequently, this places a wide duty on contracting authorities to respect Treaty principles under, otherwise, vague and untouched rules on exclusion of economic operators from public procurement practices. Therefore, the competition rules on transparency end up limiting the discretionary powers offered to contracting authorities under Article 57 of Directive 2014/24.

In the specific case at stance, the clash between the two EU policy areas is evident in the way selfcleaning programs offer leeway for undertakings to escape exclusion under Article 57(6) of Directive 2014/24 which leads to ineffectiveness and inefficacy of this provision. ${ }^{36}$ In fact, eroding

${ }^{30}$ G Skovgaard Ølykke and A Sanchez-Graells, Book Review: Reformation or Deformation of the EU Public Procurement Rules, Edward Elgar Publishing, 2016, p. 705.

${ }^{31}$ Art. 57 of Directive 2014/24, cit.

${ }^{32}$ S. de Mars, Exclusion And Self-Cleaning In Article 57: Discretion At The Expense Of Clarity And Trade?, in Reformation or Deformation of the EU Public Procurement Rules, Edward Elgar Publishing, 2016, p. 253.

${ }^{33}$ Court of Justice, judgement of 7 December 2000, case C-324/98, Telaustria Verlags GmbH and Telefonadress GmbH v Telekom Austria AG, joined party: Herold Business Data AG; Court of Justice, judgment of 21 July 2005, case C-231/03, Consorzio Aziende Metano (Coname) v Comune di Cingia de' Botti.

${ }^{34}$ Court of Justice, judgement of 16 February 2012, case C-72/10, Criminal proceedings against Marcello Costa and Ugo Cifone, para. 73.

${ }^{35}$ S. de Mars, Exclusion And Self-Cleaning In Article 57: Discretion At The Expense Of Clarity And Trade?, cit., p. 268.

${ }^{36}$ A. Sanchez-Graells, Competition and Public Procurement, in Journal of European Competition Law \& Practice, 2018, p. 557. 
such provision leads to the overall inadequacy of the objective of leniency agreements in themselves. Undertakings wishing to apply for leniency agreements will carefully consider their choice as that may lead to detrimental effects upon their position in public procurement procedures. ${ }^{37}$ In particular, leniency agreements allow for the competition authorities to gather sensitive information about the undertaking's activities in cartel cases and may lead to threats of exposition in civil damage cases. ${ }^{38}$

Some further weaknesses of the judgement can be outlined by the tension it creates between two public authorities. In allowing the contracting authorities to demand the leniency decision from the competition authority and review it in the effort to ascertain the reliability of the barred undertaking, the Court gives the contracting authority the power to have a say on the legitimacy of the works of the competition authorities, leading to an ambience of mistrust between the two bodies. ${ }^{39}$ The danger of discouraging companies from participating in leniency programs just because in waiving their confidentiality they risk being further exposed in civil liability cases has been a debate amongst various legal scholars and public enforcers. ${ }^{40}$

Nevertheless, a balance must be struck between the rights of the undertaking in question and the contracting authorities. The wide power awarded to the contracting authorities in the assimilation of information is necessary for the effective exercise of their right to compensation and to judge whether or not the application for the self-cleaning program is legitimate. ${ }^{41}$ In this regard, the protection of leniency programs is in the general interest, and the rights of contracting authorities are not absolute, especially when they need to be balanced against rights in the public interest. ${ }^{42}$ In fact, a trend in Europe has emerged following the Damages Directive 2014/104 giving prevalence to the protection for leniency agreements instead of measures that could hinder their effectiveness. ${ }^{43}$ The European Commission has emphasized this view in its policy and the CJEU has retaliated it in its jurisprudence, specifically in its decision $E n B W .{ }^{44}$ However, this predominance may be challenged by invoking the public interest also found in protecting the rights of contracting authorities; namely the right to compensation of contracting authorities allows public money that has been illegally appropriated for rigged good and/or services to be returned. ${ }^{45}$ It is in the public interest for the contracting authorities to exercise wide discretionary and investigative power in order to ascertain that the self-cleaning process is appropriate in preventing

\footnotetext{
${ }^{37}$ P.A. Giosa, Enhancing Leniency Programme In Public Markets, cit., p. 17.

${ }^{38}$ Ibid.

${ }^{39}$ Ibid., p. 16.

${ }^{40}$ Ibid., p. 17.

${ }^{41}$ Ibid., p. 18.

${ }^{42}$ Ibid.

${ }^{43}$ Ibid., p. 19.

${ }^{44}$ Court of Justice, judgement of 27 February 2014, case C-365/12, European Commission v EnBW Energie

Baden-Württemberg AG, P.A. Giosa, Enhancing Leniency Programme In Public Markets, cit., p. 19.
}

${ }^{45}$ P.A. Giosa, Enhancing Leniency Programme In Public Markets, cit., p. 19. 
the competition law breach incurred in the past from occurring again in the future and, thus, deterring future outlawed competitive behaviour. ${ }^{46}$

Therefore, the balancing between the rights of undertakings and contracting authorities needs to be judged on a case-by-case basis in order to establish the most pressing need in light to the circumstances at stance. Inevitably, in seeking to protect, on the one hand, the interests of an undertaking wishing to participate in public procurement procedures and, on the other hand, the right to compensation of the contracting authority following a competition law infringement, tensions will arise.

\section{Policy Implications}

In reviewing the relevance of the Vossloh Laies case, it is important to note, not only what the Court established, but also the potential implications of such conclusions. Such as, for instance, the interpretation of the Procurement Directive and in specific its rules on debarment, selfcleaning and leniency programmes. The case outlines how engaging with contracting authorities and applying for self-cleaning allows an economic operator to re-establish its reliability in the market, which in turn also gives grounds for denying self-cleaning procedures in other nations. ${ }^{47}$

However, there are some implications which unfolded with the opinion by AG Campos. For instance, AG Campos claims that firms do not have duties towards contracting authorities, as the AG does not consider them to fall under the term 'investigating authorities'. ${ }^{48}$ This follows from the rationale that imposing such duties on contracting authorities would create tensions between the investigating authorities and the contracting ones, whom have different nature and functions. ${ }^{49}$ However, this would imply that the victims of a cartel would not be able to bar a selfcleaning programme of an economic operator, which would act as a shield from administrative fines and civil action, as well as from exclusion in procurement procedures. ${ }^{50}$

Furthermore, the case allows for two options for the economic operator: (a) abide by the secrecy of the leniency agreement and accept the exclusion from procurement procedures; or (b) renounce this secrecy and allow the contracting authority to judge the self-cleaning procedure..$^{51}$ However, following AG Campos' arguments, this choice can be circumvented by the economic operator by delegating limited functions to the contracting authorities to investigate under Article 57(6) of Directive 2014/24.52 This circumvention of the economic operator in itself casts further doubt upon

\footnotetext{
46 A. Sanchez-Graells, Bid Rigging, Self-Cleaning, Leniency and Claims For Damages: A Beautiful Procurement Mess? (C-124/17), cit.

47 W. Kalk, 'Debarment Legislation: Its Potential As An Anti-Cartel Enforcement Tool' (Master, Vrije Universiteit Amsterdam 2019), 8.

${ }^{48}$ Opinion of AG Campos, Vossloh Laeis GmbH v Stadwerke München GmbH, cit., para 60.

${ }^{49}$ Ibid.

${ }^{50}$ A. Sanchez-Graells, Competition and Public Procurement, in Journal of European Competition Law \& Practice, cit., p. 559.

${ }^{51}$ Ibid.

${ }^{52}$ Ibid.
} 
the reliance of the firm and causes further trouble for the contracting authorities to ascertain he tenderer's self-cleaning procedure. ${ }^{53}$

Nevertheless, the European Commission itself gives guidance on how to apply the Vossloh Laeis case to fight collusion in public procurement in the March 2021 edition of the Official Journal of the European Union. Firstly, the Commission clearly argues for the contracting authorities' wide margin of appreciation in the choice of whether or not to deny the accessibility of a tenderer in a procurement procedure. ${ }^{54} \mathrm{In}$ fact, it is up to the contracting authorities to judge on a case-by-case basis whether the conditions of the case render the exclusion of an economic operator from a procurement procedure legitimate, thus, allowing the tenderer to participate even where there are enough grounds to render its exclusion. ${ }^{55}$ This follows from the rationale that the contracting authorities ought to be the one to assess the integrity and reliability of the firm, precisely because it is where the authority's trust lies. 56

Secondly, the Commission further stresses the importance of the independency of the contracting authorities in their margin of discretion. It does so by stating that the Procurement Directive does not allow Member States to oblige contracting authorities to accept tenderers' requests to participate in procurement procedures. ${ }^{57}$ This would renderer ineffective the very object of selfcleaning programs under Article 57(6), as the tenderer would have undisputed access to future procurement procedures and would not need to show any effort to re-establish its reliability vis-àvis the contracting authority. ${ }^{58}$

Another important consideration of the Vossloh Laies case is the argument brought forward in paragraph 42 of the judgment. The Court concluded that when a tenderer is excluded from procurement procedures under Article 57(4)(d) of the Procurement Directive by the competent authority, "the maximum period of exclusion is calculated from the date of the decision of that authority." 59 However, this raises significant implications in cases where that decision has not been rendered final, and only interim measures have been taken. This was the case in a Spanish decision by the Spanish National Commission on Markets and Competition ('CNMC') regarding a railroad electrification cartel.60 In this decision, the CNMC clearly prohibited the competition

\footnotetext{
53 Ibid.

${ }^{54}$ European Commission Notice of 18 March 2021 on tools to fight collusion in public procurement and on guidance on how to apply the related exclusion ground [2021] OJ C91/1, p. 13.

55 Vossloh Laeis GmbH v Stadwerke München GmbH, cit., para 23; Ibid.

56 Case C-267/18 Delta Antrepriză de Construcții şi Montaj 93 SA v Compania Națională de Administrare a Infrastructurii Rutiere SA [2019] ECR II-826, para 26.

${ }^{57}$ European Commission Notice of 18 March 2021 on tools to fight collusion in public procurement and on guidance on how to apply the related exclusion ground, cit., p. 17.

58 Case C-552/18 Indaco Service Soc. coop. sociale and Coop. sociale il Melograno v Ufficio Territoriale del Governo Taranto [2019] ECR II-997, para 27.

${ }^{59}$ Vossloh Laeis GmbH v Stadwerke München GmbH, cit., para 42.

60 Spanish National Commission on Markets and Competition Resolution S/DC/0598/2016 of 14 March 2019 on Electrification and Railroads Electrification.
} 
infringers to enter into procurement procedures but failed to state the scope and duration of this period and created further legal uncertainty by referring the case to the State Consultative Board on Public Procurement.61 However, the Court in the Vossloh Laeis case - which is to be considered directly applicable Union law - specified that de facto the maximum period of exclusion is three years. 62 Therefore, by only establishing unclear interim measures, the CNMC created a legal loophole allowing the infringers more time and a much shorter time period of exclusion.63 This decision clearly highlights the very loopholes that muddle the Vossloh Laeis judgments, as it is clear that where interim measures are established, the maximum period of exclusion needs to run also taking those decisions into account. If not, the mere litigation in competition infringement cases gives extra time to the infringers from the exclusions under the Procurement Directive.64

Inevitably, in cases of competition infringements, double interests of the European Union arise. On the one hand, the competition law objective to protect the proper functioning of the internal market, and - on the other hand - the interests of the tenderers in the financial market. ${ }^{65} \mathrm{~A}$ tension which ultimately lies in the interplay of two different EU competence areas - public procurement law and competition law - which the European bodies, and in specific the CJEU, have yet failed to appropriately balance.

\footnotetext{
${ }^{61}$ Ibid., pp. 317-320.

${ }^{62}$ Vossloh Laeis GmbH v Stadwerke München GmbH, cit., para 7.

63 A. Sanchez-Graells, 'Bid Rigging Conspiracy In Railroad Electrification Works: A Very Spanish 'Sainete' $<$ https://www.howtocrackanut.com/blog/2019/8/16/bid-rigging-in-railroad-electrification-works-a-veryspanish-sainete> accessed 4 April 2021.

${ }^{64}$ A. Sanchez-Graells, 'Litigation in Spanish Railroad Electrification Cartel Highlights Further Inadequacies of Regulation of Bid Rigger Exclusion' <https://www.howtocrackanut.com/blog/tag/vossloh+laeis> accessed 4 April 2021.

65 O. Blažo, 'Proper, Transparent And Just Prioritization Policy As A Challenge For National Competition Authorities And Prioritization Of The Slovak NCA' (2020) 13 Yearbook of Antitrust and Regulatory Studies, p. 127.
} 